Article

\title{
Immobilization of Phospholipase D on Silica-Coated Magnetic Nanoparticles for the Synthesis of Functional Phosphatidylserine
}

\author{
Qingqing Han ${ }^{1,+}{ }^{+}$, Haiyang Zhang ${ }^{1,+}$, Jianan Sun ${ }^{1, *}$, Zhen Liu ${ }^{1}$, Wen-can Huang ${ }^{1}{ }^{10}$, \\ Changhu Xue ${ }^{1,2}$ and Xiangzhao Mao ${ }^{1,2, * \text { (D) }}$ \\ 1 College of Food Science and Engineering, Ocean University of China, Qingdao 266003, China; \\ qqinghan@126.com (Q.H.); brooks29@163.com (H.Z.); liuzhenyq@ouc.edu.cn (Z.L.); \\ hwc@ouc.edu.cn (W.-c.H.); xuech@ouc.edu.cn (C.X.) \\ 2 Laboratory for Marine Drugs and Bioproducts of Qingdao National Laboratory for Marine Science and \\ Technology, Qingdao 266237, China \\ * Correspondence: sunjianan@ouc.edu.cn (J.S.); xzhmao@ouc.edu.cn (X.M.); \\ Tel.: +86-532-82031360 (J.S.); +86-532-82032660 (X.M.) \\ + Qingqing Han and Haiyang Zhang contributed to the work equally and should be regarded as \\ co-first authors.
}

Received: 22 March 2019; Accepted: 7 April 2019; Published: 15 April 2019

\begin{abstract}
In this study, silica-coated magnetic nanoparticles $\left(\mathrm{Fe}_{3} \mathrm{O}_{4} / \mathrm{SiO}_{2}\right)$ were synthesized and applied in the immobilization of phospholipase $\mathrm{D}\left(\mathrm{PLD}_{\mathrm{a} 2}\right)$ via physical adsorption and covalent attachment. The immobilized $\mathrm{PLD}_{\mathrm{a} 2}$ was applied in the synthesis of functional phosphatidylserine (PS) through a transphophatidylation reaction. The synthesis process and characterizations of the carriers were examined by scanning electron microscope (SEM), transmission electron microscope (TEM), and Fourier-transform infrared spectroscopy (FT-IR). The optimum immobilization conditions were evaluated, and the thermal and $\mathrm{pH}$ stability of immobilized and free $\mathrm{PLD}_{\mathrm{a} 2}$ were measured and compared. The tolerance to high temperature of immobilized $\mathrm{PLD}_{\mathrm{a} 2}$ increased remarkably by $10^{\circ} \mathrm{C}$. Furthermore, the catalytic activity of the immobilized $\mathrm{PLD}_{\mathrm{a} 2}$ remained at $40 \%$ after eight recycles, which revealed that silica-coated magnetic nanoparticles have potential application for immobilization and catalytic reactions in a biphasic system.
\end{abstract}

Keywords: immobilization; phospholipase D; magnetic nanoparticles; stability; phosphatidylserine

\section{Introduction}

Phospholipase D (PLD, EC 3.1.4.4) is a lipolytic enzyme which can be used to hydrolyze phospholipids (PLs), and it can also catalyze the transphosphatidylation reaction, in the presence of an alcohol [1]. To date, many works were done to better understand PLD, mainly focusing on the purification and characterization of PLD from various sources, such as plants $[2,3]$ and bacteria $[4,5]$. The analysis of PLD genes helps explain the relations between phospholipase domains and enzyme characterizations at the molecular level [6,7]. The heterologous expression of various PLD genes was reported in many kinds of microorganisms, mainly in Escherichia coli [8,9] and Streptomyces sp. [10]. The transphosphatidylation reaction is used to synthesize rare natural functional phospholipids, such as phosphatidylglycerol [11], docosahexaenoic acid-containing phosphatidylserine (DHA-PS) [12], phosphatidyl-glucose [13], and so on. Phosphatidylserine (PS), a functional phospholipid, is known to exert important physiological roles in humans [14]; it is therapeutically beneficial to improve brain function and can be used as an effective nutrient supplement in the food and pharmaceutical industries. 
Meanwhile, as the main product of transphosphatidylation catalyzed by PLD, it attracted much focus on studying its transphosphatidylation process [15].

Although researchers made many efforts to make PLD more familiar to us, at present, the industrial application of the free enzyme is still limited due to instability and unrepeatability. With the increasing awareness of environmental protection, the application of enzyme immobilization technology is receiving more attention. Five immobilization techniques are mainly used, including covalent binding, adsorption, encapsulation, entrapment, and cross-linking [16-18]. As for the immobilization of PLD, some researchers reported binding PLD via adsorption to suitable supports, such as polyacrylamide gel, calcium gel, and macroporous resin [19-21]. PLD was also cross-linked to various carriers by glutaraldehyde [22,23]. Dittrich et al. immobilized PLD from Streptomyces sp. to aminopropyl-glass activated by glutaraldehyde and used it to produce phosphatidyglycerol [23]. Younus et al. [24] reported that a recombinant cabbage PLD was immobilized on cyanogen bromide $(\mathrm{CNBr})$-activated and antibody supports through covalent binding. However, it should be emphasized that there is no universal method for any particular enzyme in the industrial settings where simplicity and cost are required. Thus, it is necessary to search for and apply new materials and methods in the immobilization of PLD.

With the development of nanotechnology, nanomaterials became a new hot area in immobilization research, especially silica-coated magnetic nanoparticles (MNPs). Indeed, these materials have many important advantages such as superparamagnetism, low toxicity, large surface area, and easy separation from the reaction system [25]. In recent years, silica-coated magnetic nanoparticles were reported to immobilize dehydrogenase [26,27], protease [28,29], lipase [30-32], glucose oxidase [33], and other enzymes. The immobilization of enzyme on such magnetic solid materials often involves covalent coupling or non-specific adsorption techniques. Adsorption is mainly based on the hydrogen bonds and hydrophobic interactions, while covalent binding is based on the reaction between functional groups of the enzyme and the carriers, mainly via a carbodiimide linkage between enzymes and MNPs $[18,27,34]$. Yu et al. reported that $\mathrm{Fe}_{3} \mathrm{O}_{4}$-chitosan and $\mathrm{Fe}_{3} \mathrm{O}_{4}$-sodium alginate were used for the immobilization of $\mathrm{PLA}_{1}$ [35] and PLA 2 [36], and the immobilized enzyme was applied to degum soybean oil.

Despite the fact that nanomaterials are widely used in enzyme immobilization, studies on the immobilization of PLD on such materials are surprisingly limited in the literature. In our previous work, we cloned and characterized $\mathrm{PLD}_{\mathrm{a} 2}$ from Acinetobacter radioresistens a2 [37], whereby the conversion rate and selectivity of PS and DHA-PS were all about $100 \%$. However, the biphasic system made it difficult to recover the free enzyme; thus, in this study, we immobilized the PLD $\mathrm{a}_{2}$ on the surface of silica-coated magnetic nanoparticles to make better use of it. The optimum immobilization conditions and characterization of the immobilized $\mathrm{PLD}_{\mathrm{a} 2}$ were investigated. Operational and storage stability of the immobilized $\mathrm{PLD}_{\mathrm{a} 2}$ were evaluated as well. The results implied that the silica-coated magnetic nanoparticles could be used in the immobilization of $\mathrm{PLD}_{\mathrm{a} 2}$; thus, the immobilization method described herein deserves further attention.

\section{Results and Discussion}

\subsection{Characterization of Silica-Coated Magnetic Nanoparticles}

The morphology and particle size of the silica-coated magnetic nanoparticles $\left(\mathrm{Fe}_{3} \mathrm{O}_{4} / \mathrm{SiO}_{2}\right)$ were observed by both scanning electron microscopy (SEM) and transmission electron microscopy (TEM). The SEM picture of $\mathrm{Fe}_{3} \mathrm{O}_{4} / \mathrm{SiO}_{2}$ particles is shown in Figure 1A, illustrating that the size of $\mathrm{Fe}_{3} \mathrm{O}_{4} / \mathrm{SiO}_{2}$ was smaller than $1 \mu \mathrm{m}$. After the reaction, the immobilized $\mathrm{PLD}_{\mathrm{a} 2}$ was separated from the reaction system using a magnet (Figure 1B). 

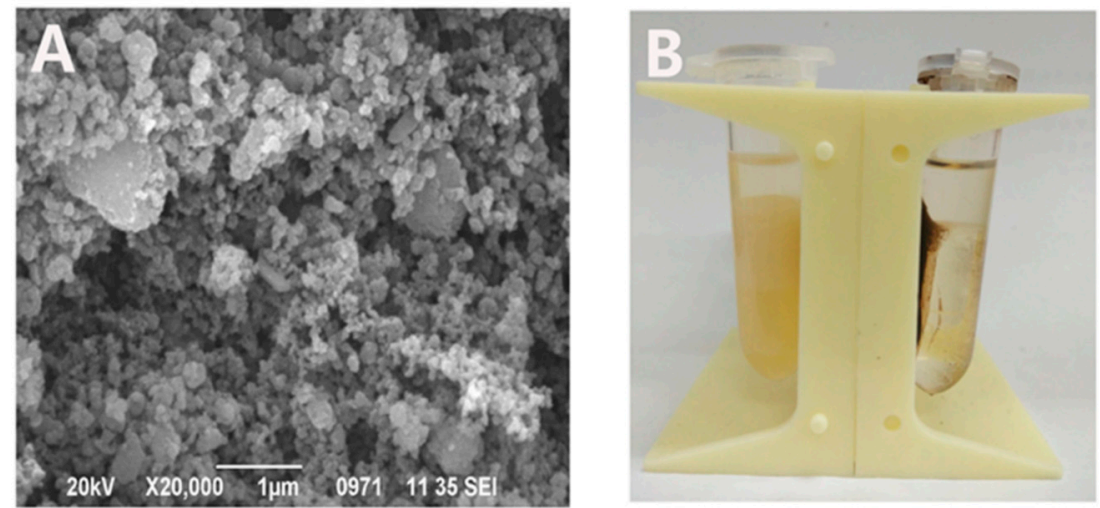

Figure 1. (A) Scanning electron microscopy picture of $\mathrm{Fe}_{3} \mathrm{O}_{4} / \mathrm{SiO}_{2}$ particles. (B) Separation of immobilized $\mathrm{PLD}_{\mathrm{a} 2}$ from reaction products using a magnet.

TEM pictures of the $\mathrm{Fe}_{3} \mathrm{O}_{4}$ and $\mathrm{Fe}_{3} \mathrm{O}_{4} / \mathrm{SiO}_{2}$ particles are shown in Figure 2, the average sizes of $\mathrm{Fe}_{3} \mathrm{O}_{4}$ and $\mathrm{Fe}_{3} \mathrm{O}_{4} / \mathrm{SiO}_{2}$ particles were about 10-15 nm and 50-60 nm, respectively. This might be explained by the magnetic properties of the particles, whereby they tended to form aggregates. After the coating process, the size of the nanoparticles increased. In Figure 2B, the black $\mathrm{Fe}_{3} \mathrm{O}_{4}$ particles seemed to be covered by a layer of a distinct gray material, which illustrated that the silica-coated magnetic nanoparticles were successfully created [30].
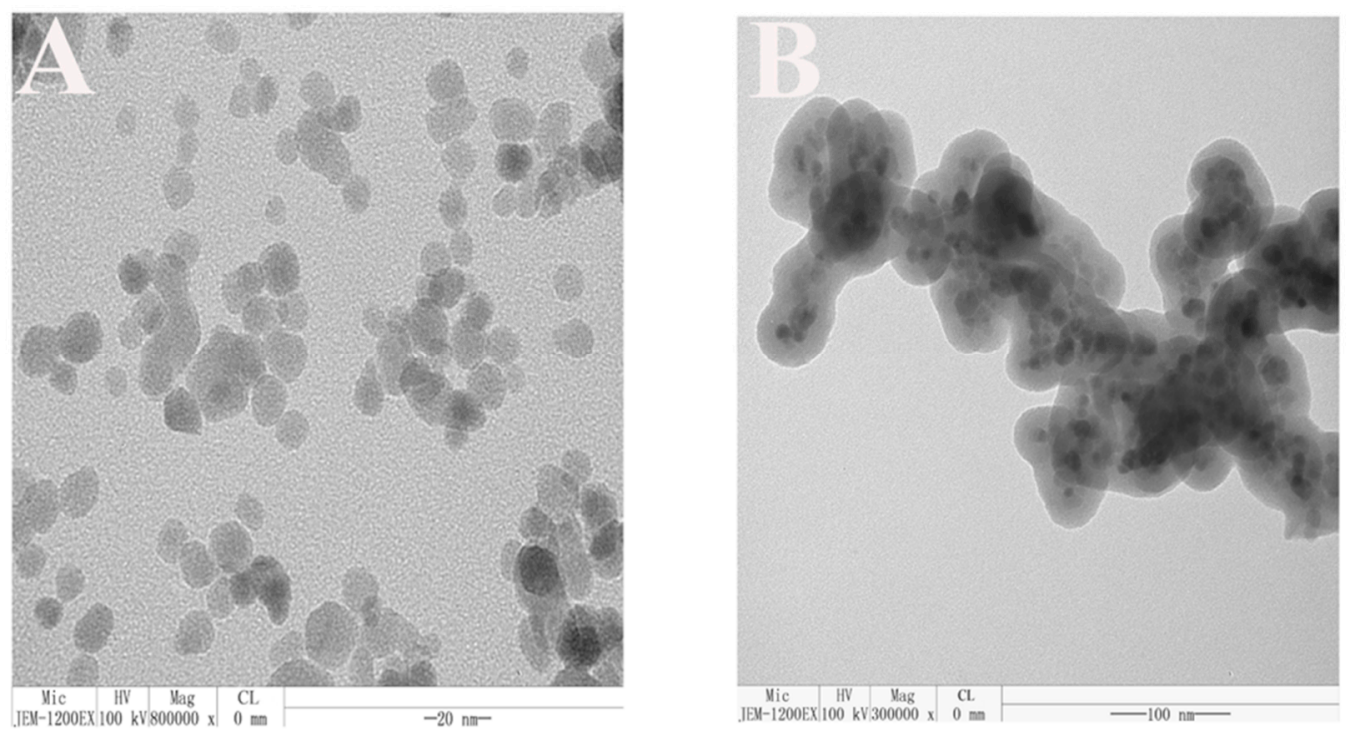

Figure 2. Transmission electron microscopy pictures of $\mathrm{Fe}_{3} \mathrm{O}_{4}(\mathbf{A})$ and $\mathrm{Fe}_{3} \mathrm{O}_{4} / \mathrm{SiO}_{2}(\mathbf{B})$ particles.

Figure 3 shows the Fourier-transform infrared (FT-IR) spectra of the $\mathrm{Fe}_{3} \mathrm{O}_{4} / \mathrm{SiO}_{2}$ particles (a), nanoparticles with bound $\operatorname{PLD}_{\mathrm{a} 2}(\mathrm{~b})$, and $\mathrm{PLD}_{\mathrm{a} 2}$ (c), which confirmed the binding of PLD $\mathrm{P}_{\mathrm{a} 2}$ on the $\mathrm{Fe}_{3} \mathrm{O}_{4} / \mathrm{SiO}_{2}$ particles, through the main band differences in the material and enzyme. There are five main characteristic peaks of pure PLD: (i) CONH peptide linkage (around $1650 \mathrm{~cm}^{-1}$ ); (ii) CN stretching vibration of amines (around $1250 \mathrm{~cm}^{-1}$ ); (iii) CH bonds (around $2950 \mathrm{~cm}^{-1}$ ); (iv) COC groups $\left(1100 \mathrm{~cm}^{-1}\right)$; (v) OH and NH vibrations (around $\left.3300 \mathrm{~cm}^{-1}\right)$. As shown in Figure 3, there are strong bands at $1650 \mathrm{~cm}^{-1}$ due to CONH peptide linkage $\left(\mathrm{PLD}_{\mathrm{a} 2}\right)$, as well as a broad peak around $1100 \mathrm{~cm}^{-1}$ attributed to $\mathrm{COC}$ groups $\left(\mathrm{PLD}_{\mathrm{a} 2}\right)$ and $\mathrm{SiO}$ groups $\left(\mathrm{Fe}_{3} \mathrm{O}_{4} / \mathrm{SiO}_{2}\right)$. The results showed that $\mathrm{PLD}_{\mathrm{a} 2}$ was successfully immobilized on the surface of silica-coated magnetic nanoparticles. 


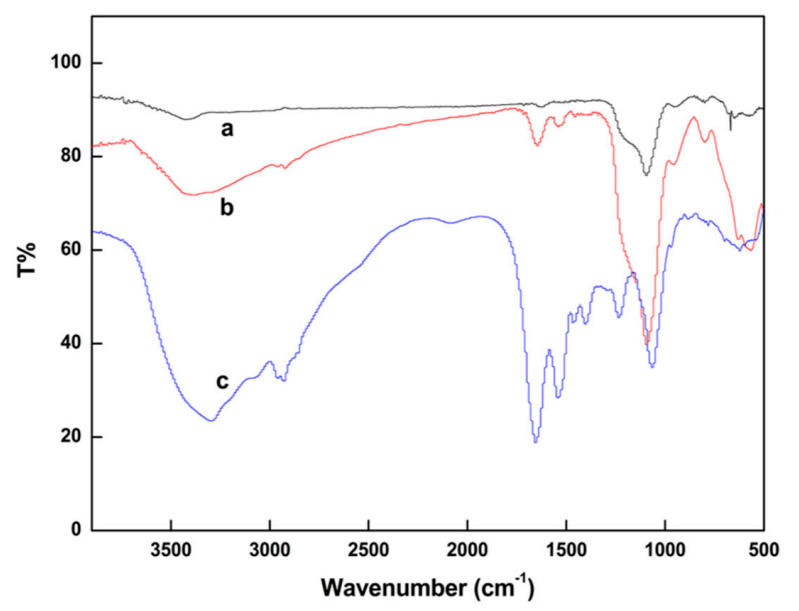

Figure 3. Fourier-transform infrared (FT-IR) spectra of $\mathrm{Fe}_{3} \mathrm{O}_{4} / \mathrm{SiO}_{2}$ particles (a), $\mathrm{Fe}_{3} \mathrm{O}_{4} / \mathrm{SiO}_{2}$ particles with bound $\operatorname{PLD}_{\mathrm{a} 2}(\mathrm{~b})$, and $\operatorname{PLD}_{\mathrm{a} 2}(\mathrm{c})$.

\subsection{Immobilized Conditions of $P L D_{a 2}$}

The optimum conditions for immobilization of $\mathrm{PLD}_{\mathrm{a} 2}$ were investigated in three aspects (the initial $\mathrm{PLD}_{\mathrm{a} 2}$ volume, the immobilization temperature, and the immobilization time), and the enzyme activity used for immobilization was $0.25 \mathrm{IU} / \mathrm{mg}$, while the enzyme concentration was $4.32 \mathrm{mg} / \mathrm{mL}$. According to the immobilization of lipase on magnetic nanoparticles [30], $10 \mathrm{mg}$ of $\mathrm{Fe}_{3} \mathrm{O}_{4} / \mathrm{SiO}_{2}$ particles was firstly dispersed in different volumes of $\mathrm{PLD}_{\mathrm{a} 2}$ liquid. As shown in Figure $4 \mathrm{~A}$, it was found that a combination of $1.0 \mathrm{~mL}$ of $\mathrm{PLD}_{\mathrm{a} 2}$ liquid with $10 \mathrm{mg} \mathrm{Fe} \mathrm{O}_{4} / \mathrm{SiO}_{2}$ particles obtained the highest enzyme activity. This might be due to the lower volume of $\mathrm{PLD}_{\mathrm{a} 2}$, resulting in less protein absorbed to the carriers. However, the surface area of the carrier was limited, and too much enzyme liquid led to the coverage of the catalytic sites, thus, more enzyme did not equate to higher activity [18].
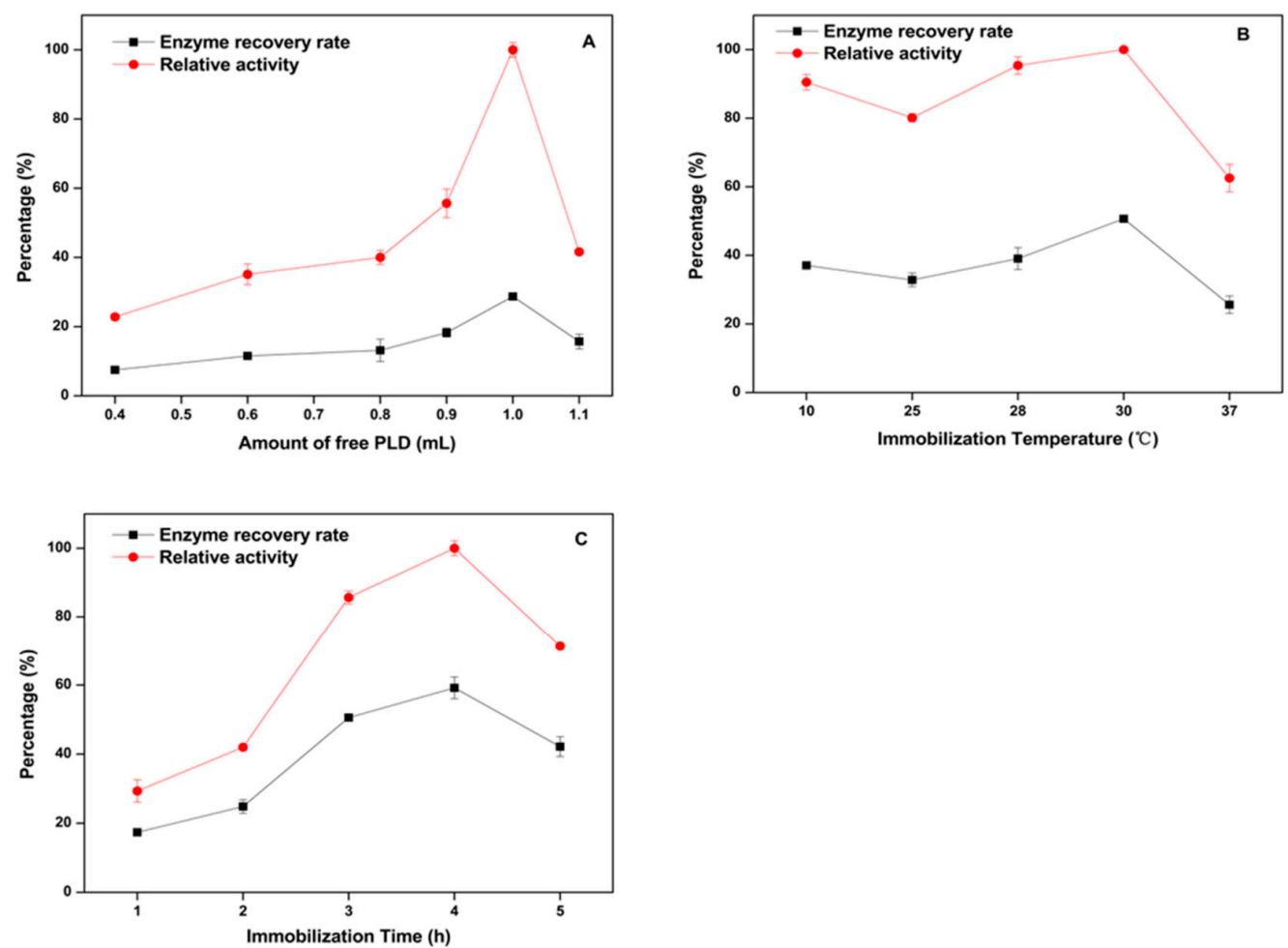

Figure 4. The effect of the initial $\operatorname{PLD}_{\mathrm{a} 2}$ volume(A), temperature (B), and reaction time $(\mathrm{C})$ on the enzyme recovery rate and the relative activity. 
The optimum temperature of immobilization was also determined by the final enzyme recovery rate and the relative enzyme activity. About $10 \mathrm{mg}$ of $\mathrm{Fe}_{3} \mathrm{O}_{4} / \mathrm{SiO}_{2}$ particles was dispersed in $1.0 \mathrm{~mL}$ of $\mathrm{PLD}_{\mathrm{a} 2}$ liquid and shaken at different temperatures for $5 \mathrm{~h}$. In this part, the optimum temperature proved to be $30^{\circ} \mathrm{C}$, as shown in Figure $4 \mathrm{~B}$.

As shown in Figure 4C, by increasing the reaction time from 1 to $5 \mathrm{~h}$, the enzyme recovery rate increased, with reaction conditions of $1.0 \mathrm{~mL}$ of the initial $\mathrm{PLD}_{\mathrm{a} 2}$ volume at a temperature of $30^{\circ} \mathrm{C}$. The relative activity of immobilized PLD increased to maximum after $4 \mathrm{~h}$. Compared to other methods, the immobilization time of this nanotechnology was shorter, as the covalent immobilization of PLD to VA-Epoxy Biosynth took $72 \mathrm{~h}$ [32] and it took $24 \mathrm{~h}$ to immobilize PLD on CNBr-activated supports [24].

Therefore, the immobilized PLD $\mathrm{a}_{2}$ under the optimum conditions was further characterized and applied in a subsequent study. The enzyme recovery rate reached $59.16 \%$ at optimum conditions for the immobilization of $\mathrm{PLD}_{\mathrm{a} 2}$. However, Ranjbakhsha et al. [30] reported the immobilization yield of lipase on such materials was $44.28 \%$ at optimum conditions.

\subsection{Characterization of Immobilized $P L D_{a 2}$}

2.3.1. Effect of Temperature on the Activity and Stability of Free and Immobilized PLD $\mathrm{a}_{2}$

The optimum temperatures of the free and immobilized $\mathrm{PLD}_{\mathrm{a} 2}$ are shown in Figure $5 \mathrm{~A}$. The optimum operational temperature of the immobilized $\mathrm{PLD}_{\mathrm{a} 2}\left(50^{\circ} \mathrm{C}\right)$ was raised by $10^{\circ} \mathrm{C}$ compared to the free $\operatorname{PLD}_{\mathrm{a} 2}\left(40^{\circ} \mathrm{C}\right)$ [37]. This might be explained by the protection effect of the carriers, which decrease the exposure of the immobilized $\mathrm{PLD}_{\mathrm{a} 2}$ to temperature. As the temperature ranged from 20 to $60^{\circ} \mathrm{C}$, the immobilized $\mathrm{PLD}_{\mathrm{a} 2}$ showed less sensitivity to the change in temperature. This result is consistent with works described by Li et al. [38], where, after immobilizing PLD on non-porous nanoparticles, the optimum temperature $\left(35^{\circ} \mathrm{C}\right)$ was raised by $5^{\circ} \mathrm{C}$ compared to free $\operatorname{PLD}\left(30^{\circ} \mathrm{C}\right)$.
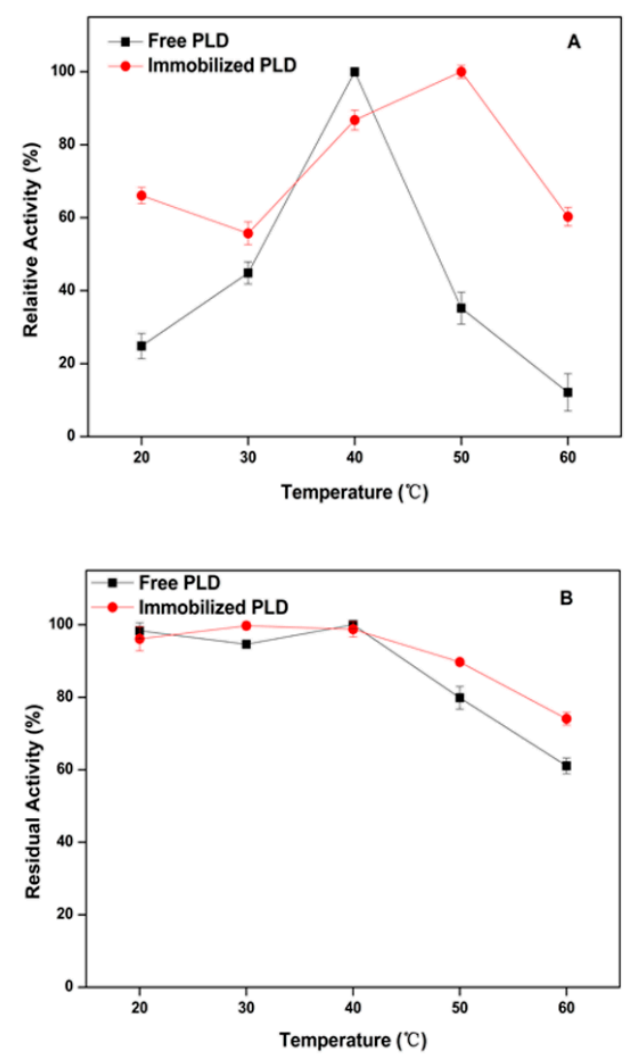

Figure 5. Effect of temperature on the enzyme activity (A) and stability (B) of the free and immobilized PLD $\mathrm{a}_{\mathrm{a}}$. 
The thermal stability of the free and immobilized $\mathrm{PLD}_{\mathrm{a} 2}$ in the range of $20-60^{\circ} \mathrm{C}$ is shown in Figure $5 \mathrm{~B}$, the results demonstrate that the immobilized $\mathrm{PLD}_{\mathrm{a} 2}$ had better tolerance to high temperature and it was more stable than free $\mathrm{PLD}_{\mathrm{a} 2}$ at different temperatures. However, immobilization does not ensure the improvement of enzyme characterizations. Younus et al. [24] showed that binding recombinant cabbage PLD to the antibody supports rendered the enzyme labile at high temperature. The better thermal stability of immobilized $\mathrm{PLD}_{\mathrm{a} 2}$ may be due to the formation of multipoint interactions, since there are hydrogen, ionic, and hydrophobic interactions between the PLD $\mathrm{a}_{2}$ and nanoparticles, which may protect $\mathrm{PLD}_{\mathrm{a} 2}$ from deactivation [32].

\subsubsection{Effect of $\mathrm{pH}$ on the Activity and Stability of Free and Immobilized $\mathrm{PLD}_{\mathrm{a} 2}$}

The results in Figure 6A reveal the optimum $\mathrm{pH}$ of free and immobilized $\mathrm{PLD}_{\mathrm{a} 2}$, whereby both of them obtained the highest activity in acidic conditions. However, on the other hand, the immobilized $\mathrm{PLD}_{\mathrm{a} 2}$ performed better in alkaline conditions. A similar phenomenon was reported by Lambrecht et al. [20], where it was shown that immobilization of PLD on octyl-sepharose resulted in an enlarged $\mathrm{pH}$ optimum range. This is possibly due to the support surface affording protection for the enzyme or the catalytic sites, rendering it less effective as $\mathrm{pH}$ changes in the reaction system.

The $\mathrm{pH}$ stability of the free and immobilized $\mathrm{PLD}_{\mathrm{a} 2}$ was measured, and the results are shown in Figure 6B. It can be seen that, after being exposed to different $\mathrm{pH}$ for $12 \mathrm{~h}$, the immobilized $\mathrm{PLD}_{\mathrm{a} 2}$ was more stable and the enzyme activity changed less sharply.
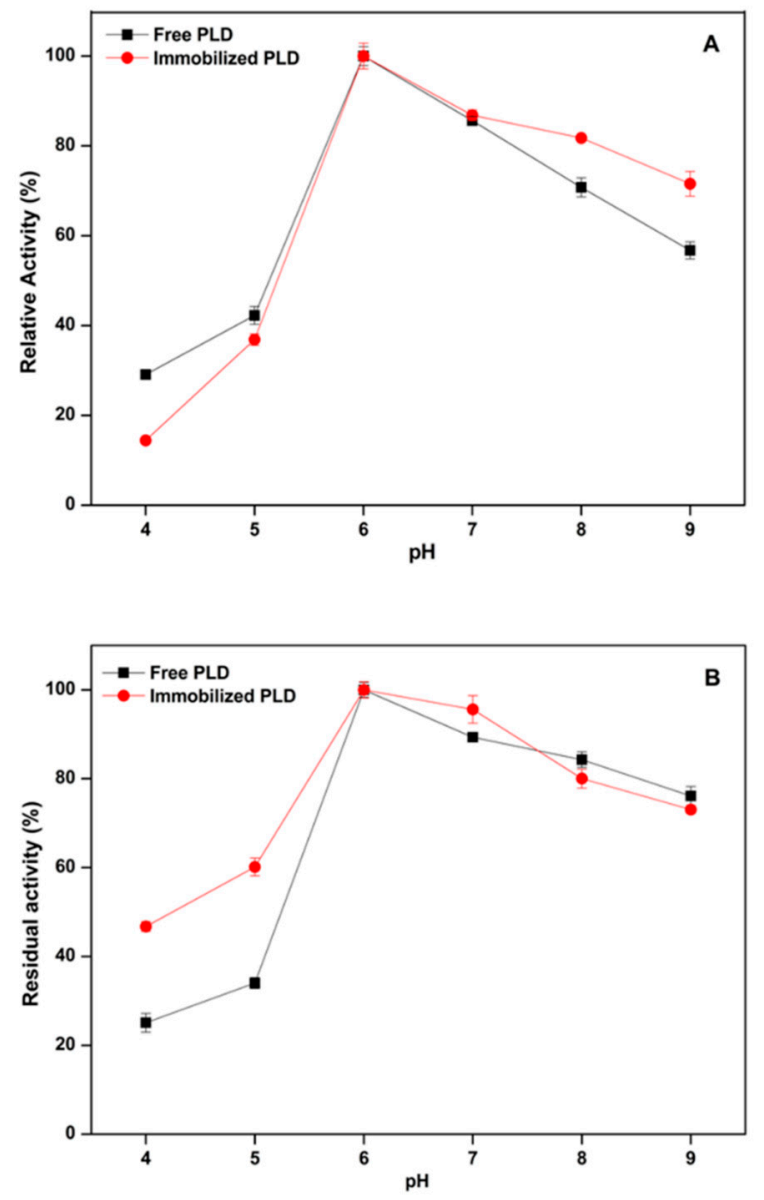

Figure 6. Effect of $\mathrm{pH}$ on the enzyme activity (A) and stability (B) of the free and immobilized $\mathrm{PLD}_{\mathrm{a} 2}$. 


\subsubsection{Operational and Storage Stability of Immobilized $P L D_{a}$}

Reusability is a very important feature to evaluate the characteristics of immobilized PLD. There are two aspects to assess the operational stability of the immobilized PLD $\mathrm{a}_{\mathrm{a} 2}$ : hydrolysis activity and the transphosphatidylation activity. At the end of each batch, the immobilized $\mathrm{PLD}_{\mathrm{a} 2}$ was separated and recycled from the reaction system using a magnet. As shown in Figure 7, reusability presented a descending trend after seven times, whereby the hydrolysis activity remained higher than $40 \%$, while the transphosphatidylation activity remained around $20 \%$. The difference $n$ results between these two measurement methods might be caused by the amount of immobilized PLD $\mathrm{a}_{2}$ and the different reaction conditions. More enzyme was added to catalyze the transphosphatidylation reaction in a biphasic system, and damage of the enzymes was induced by organic solvents.
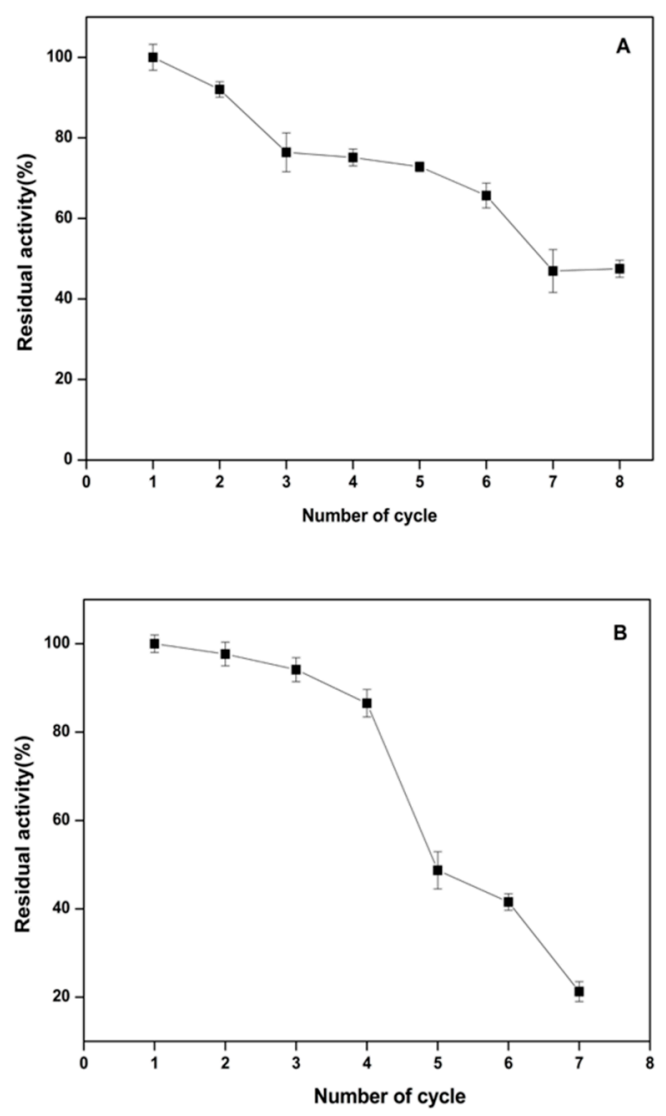

Figure 7. Operational stability of immobilized $\mathrm{PLD}_{\mathrm{a} 2}$ in subsequent cycles of hydrolysis activity (A) and transphophatidylation (B).

Considering the production costs in industrial application, the reusability of an enzyme was proven to be a dominant characteristic of immobilization technology. The storage stability of immobilized $\mathrm{PLD}_{\mathrm{a} 2}$ is shown in Figure 8, the immobilized $\mathrm{PLD}_{\mathrm{a} 2}$ retained more than $60 \%$ of its initial activity after storage at $4^{\circ} \mathrm{C}$ for seven days. This indicated success in the immobilization of PLD on magnetic nanoparticles, in spite of a better effect on reusability and storage stability of the immobilized $\mathrm{PLD}_{\mathrm{a} 2}$ in other reports $[20,30]$. 


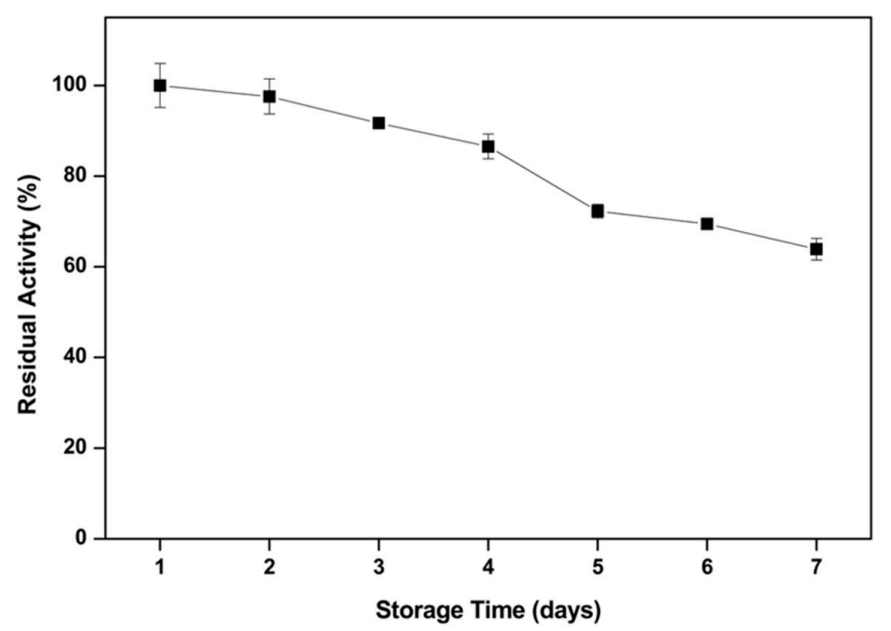

Figure 8. Storage stability of immobilized $\mathrm{PLD}_{\mathrm{a} 2}$. The immobilized $\mathrm{PLD}_{\mathrm{a} 2}$ was stored at $4^{\circ} \mathrm{C}$ for several days.

\section{Materials and Methods}

\subsection{Materials}

L- $\alpha$-Phosphatidylcholine (95\%) was purchased from Avanti (Alabama, USA); L-serine was purchased from Solarbio (Beijing, China); choline oxidase and peroxidase were purchased from Sigma-Aldrich (St. Louis, MO, USA). All other reagents used were of standard laboratory grade unless otherwise stated.

The strain $A$. radioresistens a2 was obtained from oil refineries, and the gene encoding for the $\mathrm{PLD}_{\mathrm{a} 2}$ was cloned and expressed in E. coli BL21(DE3) [37].

\subsection{Production of Enzyme PLDa2}

The strains were used as sources of recombinant $E$. coli, and $\mathrm{PLD}_{\mathrm{a} 2}$ was cloned from $A$. radioresistens a2. The E. coli strains were grown in Luria-Bertani (LB) medium, which comprised ( $w / v) 0.5 \%$ tryptone, $0.1 \%$ yeast extract, and $0.1 \% \mathrm{NaCl}$, at $37^{\circ} \mathrm{C}$ with $50 \mu \mathrm{g} / \mathrm{mL}$ kanamycin (Solarbio, Beijing, China). Overexpression of PLD $_{\mathrm{a} 2}$ was induced by ZYP-5052 complete medium with kanamycin, incubating at $20^{\circ} \mathrm{C}$ for $48 \mathrm{~h}$. The cells were sonicated in an ice bath and the $\mathrm{PLD}_{\mathrm{a} 2}$ was collected by centrifugation. The enzyme samples for immobilization were prepared through filtering the crude extracts using a $0.45-\mu \mathrm{m}$ ultrafilter.

\subsection{Preparation and Characterization of Silica-Coated Magnetic Nanoparticles}

The silica-coated magnetic nanoparticles were prepared according to the modified method described by Ranjbakhsh et al. [30]. Briefly, the co-precipitation method was used to prepare magnetic iron-oxide nanoparticles, and the nanoparticles were coated with silica via a sol-gel reaction. The size and structure of the silica-coated magnetic nanoparticles were determined by transmission electron microscopy (TEM) and scanning electron microscopy (SEM). Fourier-transform infrared spectroscopy

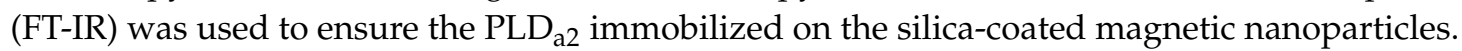

\subsection{Enzyme Immobilization on Silica-Coated Magnetic Nanoparticles}

Firstly, $10 \mathrm{mg}$ of silica-coated magnetic nanoparticles was taken for each sample, which was then dispersed in the enzyme liquid with various volumes $(0.4 \mathrm{~mL}, 0.6 \mathrm{~mL}, 0.8 \mathrm{~mL}, 0.9 \mathrm{~mL}, 1.0 \mathrm{~mL}$, and $1.1 \mathrm{~mL})$. The mixture was shaken at different temperatures $\left(10^{\circ} \mathrm{C}, 25^{\circ} \mathrm{C}, 28^{\circ} \mathrm{C}, 30^{\circ} \mathrm{C}\right.$, and $\left.37^{\circ} \mathrm{C}\right)$ for 1-5 h. The immobilized $\mathrm{PLD}_{\mathrm{a} 2}$ was recovered via magnetic separation, and the resulting immobilized $\mathrm{PLD}_{\mathrm{a} 2}$ was washed with Tris- $\mathrm{HCl}$ buffer $(20 \mathrm{mM}, \mathrm{pH}=7.4)$ at least three times. Then, the activity of the 
immobilized PLDa2 was measured, and the optimum conditions were based on the enzyme activity of the immobilized PLD $\mathrm{a}_{\mathrm{a}}$.

\subsection{Characterization of Free and Immobilized Enzymes}

To evaluate the effect of temperature on free and immobilized $\mathrm{PLD}_{\mathrm{a} 2}$, the reactions were conducted at different temperatures $\left(20^{\circ} \mathrm{C}, 30^{\circ} \mathrm{C}, 40^{\circ} \mathrm{C}, 50^{\circ} \mathrm{C}\right.$, and $\left.60^{\circ} \mathrm{C}\right)$ at $\mathrm{pH} 7.4$, and the enzyme activity was measured with other conditions unchanged. To determine the temperature stability, free and immobilized $\mathrm{PLD}_{\mathrm{a} 2}$ samples were pre-incubated at $20-60^{\circ} \mathrm{C}$ with $\mathrm{pH} 7.4$ for $4 \mathrm{~h}$; then, the residual activity was measured under standard assay conditions.

As for the effect of $\mathrm{pH}$ on free and immobilized $\mathrm{PLD}_{\mathrm{a} 2}$, the procedure was similar to the temperature experiments above. However, the reactions were conducted in a $\mathrm{pH}$ range of 4.0-9.0. To determine the $\mathrm{pH}$ stability, free and immobilized $\mathrm{PLD}_{\mathrm{a} 2}$ samples were pre-incubated at $4^{\circ} \mathrm{C}$ at different $\mathrm{pH}(4.0-9.0)$ for $12 \mathrm{~h}$; then, the residual activity was measured under standard assay conditions.

\subsection{Operating Stability Assay}

The operating stability of the immobilized $\mathrm{PLD}_{\mathrm{a} 2}$ was measured by quantifying its catalyst activity in consecutive cycles of repeated use. After each batch reaction, the immobilized PLD $_{\mathrm{a} 2}$ was recovered by magnetic separation; then, the resulting immobilized $\mathrm{PLD}_{\mathrm{a} 2}$ was washed with Tris- $\mathrm{HCl}$ buffer $(20 \mathrm{mM}, \mathrm{pH}=7.4)$ at least three times before being used for the next batch reaction. Through adding fresh substrates, the immobilized PLD $_{\mathrm{a} 2}$ was reused for a number of cycles. Both the hydrolysis activity and the transphosphatidylation activity of the immobilized PLD $_{\mathrm{a} 2}$ were measured.

\subsection{Storage Stability Assay}

The storage stability of the immobilized PLD $\mathrm{P}_{\mathrm{a}}$ was determined by its residual activity after incubation at $4{ }^{\circ} \mathrm{C}$ in Tris-HCl buffer $(20 \mathrm{mM}, \mathrm{pH}=7.4)$. The residual activity after different lengths of storage (one day, two days, three days, four days, five days, six days, and seven days) was assayed in conditions as described above.

\subsection{Determination of Hydrolysis Activity}

The enzyme activity of $\mathrm{PLD}_{\mathrm{a} 2}$ constituted two assays: hydrolysis activity and transphosphatidylation activity [4]. The hydrolysis activity was measured using the method developed by Imamura and Horiuti with modifications [39]. The reaction mixture was composed of $100 \mu \mathrm{L}$ of $10 \mathrm{mg} / \mathrm{mL} \mathrm{PC}, 10 \mu \mathrm{L}$ of $0.1 \mathrm{M}$ citric acid buffer (pH 6.0), $5 \mu \mathrm{L}$ of $0.1 \mathrm{M} \mathrm{CaCl}_{2}$, and $100 \mu \mathrm{L}$ of the enzyme solution. The reaction was conducted at $37^{\circ} \mathrm{C}$ for $25 \mathrm{~min}$, and stopped by adding $20 \mu \mathrm{L}$ of $50 \mathrm{mM}$ ethylenediaminetetraacetic acid (EDTA) in $1 \mathrm{M}$ Tris- $\mathrm{HCl}$ buffer ( $\mathrm{pH} 8.0)$. The resulting mixture was mixed with $200 \mu \mathrm{L}$ of a solution of $0.5 \mathrm{U}$ of choline oxidase, $0.2 \mathrm{U}$ of peroxidase, $0.2 \mathrm{mg}$ of 4-aminoantipyrine, $0.1 \mathrm{mg}$ of phenol, and $2 \mathrm{mg}$ of TritonX-100 in $1 \mathrm{M}$ Tris-Hcl buffer ( $\mathrm{pH} 8.0$ ). After a 3-h reaction at $37^{\circ} \mathrm{C}$, with the catalysis of choline oxidase and peroxidase, the intermediate products finally transformed to quinoneimine dye, whose absorbancy could be measured using an enzyme-linked colorimeter at $500 \mathrm{~nm}$.

\subsection{High-Performance Liquid Chromatography (HPLC) Assay}

The transphosphatidylation reaction was performed in a biphasic system with PC and serine as substrates. The reaction mixture was composed of $1.0 \mathrm{~mL}$ of $0.2 \mathrm{M}$ sodium acetate/acetic acid buffer ( $\mathrm{pH}$ 6.2, including $1.0 \mathrm{M}$ serine and $0.1 \mathrm{M} \mathrm{CaCl}_{2}$ ) and $1.0 \mathrm{~mL}$ of $20 \mathrm{mg} / \mathrm{mL}$ PC dissolved in ethyl ether. The reaction was conducted at $40^{\circ} \mathrm{C}$ for $12 \mathrm{~h}$. The transphosphatidylation activity was determined from the PS conversion ratio, defined as $100 \times$ PS/ (PC + PA + PS). The composition of the production after reaction was analyzed using an evaporative light scattering detector (ELSD) HPLC (Waters, USA). All HPLC experiments were conducted as follows: after nitrogen drying, 
the products obtained from the reaction mixture were dissolved in hexane/isopropanol $(81.42: 17, v / v)$, then filtered using a $0.22-\mu \mathrm{m}$ ultrafiltrate membrane. Parameters were as follows: $250 \mathrm{~mm} \times 4.5 \mathrm{~mm}$ YMC DIOL column with 5- $\mu \mathrm{m}$ particle diameter, nitrogen as the nebulizing gas at a pressure of $25 \mathrm{psi}$, with a power level of $60 \%$ and a temperature setting of $50^{\circ} \mathrm{C}$. The elution program was a nonlinear gradient with buffer A (hexane:isopropanol:acetic acid:triethylamine $=81.42: 17: 1.5: 0.08(v / v / v / v))$ and buffer B (isopropanol:water:acetic acid:triethylamine $=84.42: 14: 1.5: 0.08(v / v / v / v)$ ). The flow rate was $1 \mathrm{~mL} / \mathrm{min}$, the injection volume was $10 \mu \mathrm{L}$, and the column was equilibrated at $55^{\circ} \mathrm{C}$. In these conditions, the proposed method was able to separate the reaction products as PA, PC, and PS.

\section{Conclusions}

Herein, we described the preparation method of silica-coated magnetic nanoparticles $\left(\mathrm{Fe}_{3} \mathrm{O}_{4} / \mathrm{SiO}_{2}\right)$ and their effective application for the immobilization of phospholipase $\mathrm{D}$ via physical adsorption and covalent attachment. FT-IR spectra proved the immobilization of PLD on the magnetic supports. The enzyme recovery rate reached $59.16 \%$ at optimum conditions (10 $\mathrm{mg}$ of silica-coated magnetic nanoparticles dispersed in $1.0 \mathrm{~mL}$ of enzyme liquid at $30^{\circ} \mathrm{C}$ for $4 \mathrm{~h}$ ) for immobilization of $\mathrm{PLD}_{\mathrm{a} 2}$.

In addition, the immobilized $\mathrm{PLD}_{\mathrm{a} 2}$ had better tolerance to high temperature, and its optimum temperature was $10^{\circ} \mathrm{C}$ higher than that of free enzyme. Furthermore, the successful immobilization of PLD allowed its recovery and reuse in the synthesis of functional phosphatidylserine (PS). After reuse for the seventh time, the hydrolysis activity remained above $40 \%$, while the transphosphatidylation activity remained around $20 \%$. Therefore, silica-coated magnetic nanoparticles $\left(\mathrm{Fe}_{3} \mathrm{O}_{4} / \mathrm{SiO}_{2}\right)$ may have a promising future as materials for various biocatalyst reactions, and such immobilization methods could be applied in more fields.

Author Contributions: Conceptualization, J.S. and X.M.; data curation, Q.H. and H.Z.; formal analysis, Q.H. and H.Z.; funding acquisition, J.S., C.X., and X.M.; investigation, W.-c.H.; methodology, Z.L.; project administration, J.S., C.X., and X.M.; resources, C.X.; supervision, Z.L., W.-c.H., and X.M.; writing—original draft, Q.H.; writing一review and editing, H.Z.

Funding: This work was supported by the National Natural Science Foundation of China (31501516), the Taishan Scholar Project of Shandong Province (NO. tsqn201812020), the Applied Basic Research Program of Qingdao (16-5-1-18-jch), the Major Special Science and Technology Projects in Shandong Province (2016YYSP016), and the Laboratory for Marine Drugs and Bioproducts of Qingdao National Laboratory for Marine Science and Technology (LMDBKF201705).

Conflicts of Interest: The authors declare no conflicts of interest.

\section{References}

1. Waite, M. The PLD superfamily: Insights into catalysis. Biochim. Biophys. Acta 1999, 1439, 187-197. [CrossRef]

2. Hanahan, D.J.; Chaikoff, I.L. A new phospholipide-splitting enzyme specific for the ester linkage between the nitrogenous base and the phosphoric acid grouping. J. Biol. Chem. 1947, 169, 699-705. [PubMed]

3. Khatoon, H.; Mansfeld, J.; Schierhorn, A.; Ulbrich-Hofmann, R. Purification, sequencing and characterization of phospholipase D from Indian mustard seeds. Phytochemistry 2015, 117, 65-75. [CrossRef]

4. Carrea, G.; D'Arrigo, P.; Piergianni, V.; Roncaglio, S.; Secundo, F.; Servi, S. Purification and properties of two phospholipases D from Streptomyces sp. Biochim. Biophys. Acta 1995, 1255, 273-279. [CrossRef]

5. Simkhada, J.R.; Cho, S.S.; Hong, S.C.; Si, W.K.; Lee, H.C.; Sohng, J.K.; Jin, C.Y. A new thermolabile alkaline phospholipase D from Streptomyces sp. CS628. Biotechnol. Bioprocess 2010, 15, 595-602. [CrossRef]

6. Nakazawa, Y.; Sato, H.; Uchino, M.; Takano, K. Purification, characterization and cloning of phospholipase D from peanut seeds. Protein J. 2006, 25, 212-223. [CrossRef]

7. Yang, N.; Yue, X.L.; Chen, X.L.; Wu, G.F.; Zhang, T.G.; An, L.Z. Molecular cloning and partial characterization of a novel phospholipase D gene from Chorispora bungeana. Plant Cell Tiss. Org. 2012, 108, 201-212. [CrossRef]

8. Yang, H.Y.; Roberts, M.F. Expression and characterization of a heterodimer of Streptomyces chromofuscus phospholipase D. Biochim. Biophys. Acta 2004, 1703, 43-51. [CrossRef] [PubMed] 
9. Zambonelli, C.; Morandi, P.; Vanoni, M.A.; Tedeschi, G.; Servic, S.; Curti, B. Cloning and expression in Escherichia coli of the gene encoding Streptomyces PMF PLD, a phospholipase D with high transphosphatidylation activity. Enzym. Microb. Technol. 2003, 33, 676-688. [CrossRef]

10. Ogino, C.; Kanemasu, M.; Hayashi, Y.; Kondo, A.; Shimizu, N.; Tokuyama, S.; Tahara, Y.; Kuroda, S.; Tanizawa, K.; Fukuda, H. Over-expression system for secretory phospholipase D by Streptomyces lividans. J. Biotechnol. 2004, 64, 823-828. [CrossRef] [PubMed]

11. Simkhada, J.R.; Lee, H.J.; Jang, S.Y.; Kim, J.H.; Lee, H.C.; Sohng, J.K.; Yoo, J.C. A novel low molecular weight phospholipase D from Streptomyces sp. CS684. Bioresour. Technol. 2009, 99, 1388-1393. [CrossRef]

12. Hosokawa, M.; Shimatani, T.; Kanada, T.; Inoue, Y.; Takahashi, K. Conversion to docosahexaenoic acid-containing phosphatidylserine from squid skin lecithin by phospholipase D-mediated transphosphatidylation. J. Agric. Food Chem. 2000, 48, 4550-4554. [CrossRef]

13. Song, S.; Cheong, L.Z.; Guo, Z.; Kristensen, K.; Glasius, M.; Jensen, H.M.; Bertelsen, K.; Tan, T.; Xu, X. Phospholipase D (PLD) catalyzed synthesis of phosphatidyl-glucose in biphasic reaction system. Food Chem. 2012, 135, 373-379. [CrossRef] [PubMed]

14. Vance, J.E. Phosphatidylserine and phosphatidylethanolamine in mammalian cells: Two metabolically related aminophospholipids. J. Lipid Res. 2008, 49, 1377-1387. [CrossRef]

15. D'Arrigo, P.; Cerioli, L.; Chiappe, C.; Panzeri, W.; Tessaro, D.; Mele, A. Improvements in the enzymatic synthesis of phosphatidylserine employing ionic liquids. J. Mol. Catal. B Enzym. 2012, 84, 132-135. [CrossRef]

16. Jesionowski, T.; Zdarta, J.; Krajewska, B. Enzyme immobilization by adsorption: A review. Adsorption 2014, 20, 801-821. [CrossRef]

17. Urszula, G.; Katarzyna, H.-K.; Danuta, W. Immobilization as a strategy for improving enzyme properties-application to oxidoreductases. Molecules 2014, 19, 8995-9018.

18. Wang, W.; Guo, N.; Huang, W.; Zhang, Z.; Mao, X. Immobilization of chitosanases onto magnetic nanoparticles to enhance enzyme performance. Catalysts 2018, 8, 401. [CrossRef]

19. Juneja, L.R.; Hibi, N.; Yamane, T.; Shimizu, S. Repeated batch and continuous operations for phosphatidylglycerol synthesis from phosphatidylcholine with immobilized phospholipase D. Appl. Microbiol. Biotechnol. 1987, 27, 146-151. [CrossRef]

20. Lambrecht, R.; Ulbrich-Hofmann, R. The adsorptive immobilization of phospholipids D mediated by calcium ions. Biotechnol. Bioeng. 1993, 41, 833-836. [CrossRef]

21. Yon, J.O.; Ji, S.L.; Bo, G.K.; Sang, D.K.; Nam, D.H. Immobilization of Streptomyces phospholipase D on a Dowex macroporous resin. Biotechnol. Bioprocess 2008, 13, 102-107. [CrossRef]

22. Wang, X.G.; Qui, A.Y.; Tao, W.Y.; Shen, P.Y. Synthesis of phosphatidylglycerol from soybean lecithin with immobilized phospholipase D. J. Am. Oil Chem. Soc. 1997, 74, 87-91. [CrossRef]

23. Dittrich, N.; Ulbrich-Hofmann, R. Transphosphatidylation by immobilized phospholipase D in aqueous media. Biotechnol. Appl. Biochem. 2001, 34, 189-194. [CrossRef]

24. Younus, H.; Rajcani, J.; Ulbrich-Hofmann, R.; Saleemuddin, M. Behaviour of a recombinant cabbage (Brassica oleracea) phospholipase D immobilized on CNBr-activated and antibody supports. Biotechnol. Appl. Biochem. 2004, 40, 95-99. [PubMed]

25. Xu, J.; Sun, J.; Wang, Y.; Sheng, J.; Wang, F.; Sun, M. Application of iron magnetic nanoparticles in protein immobilization. Molecules 2014, 19, 11465-11486. [CrossRef]

26. Liao, M.H.; Chen, D.H. Immobilization of yeast alcohol dehydrogenase on magnetic nanoparticles for improving its stability. Biotechnol. Lett. 2001, 23, 1723-1727. [CrossRef]

27. Johnson, A.K.; Zawadzka, A.M.; Deobald, L.A.; Crawford, R.L.; Paszczynski, A.J. Novel method for immobilization of enzymes to magnetic nanoparticles. J. Nanopart. Res. 2008, 10, 1009-1025. [CrossRef]

28. Wang, T.H.; Lee, W.C. Immobilization of proteins on magnetic nanoparticles. Biotechnol. Bioprocess 2003, 8 , 263-267. [CrossRef]

29. Li, D.; Teoh, W.Y.; Gooding, J.J.; Selomulya, C.; Amal, R. Functionalization Strategies for Protease Immobilization on Magnetic Nanoparticles. Adv. Funct. Mater. 2010, 20, 1767-1777. [CrossRef]

30. Ranjbakhsh, E.; Bordbar, A.K.; Abbasi, M.; Khosropour, A.R.; Shams, E. Enhancement of stability and catalytic activity of immobilized lipase on silica-coated modified magnetite nanoparticles. Chem. Eng. J. 2012, 179, 272-276. [CrossRef] 
31. Cui, J.; Cui, L.; Jia, S.; Su, Z.; Zhang, S. Hybrid cross-linked lipase aggregates with magnetic nanoparticles: A robust and recyclable biocatalysis for epoxidation of oleic acid. J. Agric. Food Chem. 2016, 64, 7179-7187. [CrossRef] [PubMed]

32. Gao, J.; Kong, W.; Zhou, L.; He, Y.; Ma, L.; Wang, Y.; Yin, L.; Jiang, Y. Monodisperse core-shell magnetic organosilica nanoflowers with radial wrinkle for lipase immobilization. Chem. Eng. J. 2017, 309, 70-79. [CrossRef]

33. Huang, J.; Zhao, R.; Wang, H.; Zhao, W.; Ding, L. Immobilization of glucose oxidase on $\mathrm{Fe}_{3} \mathrm{O}_{4} / \mathrm{SiO}_{2}$ magnetic nanoparticles. Biotechnol. Lett. 2010, 32, 817-821. [CrossRef] [PubMed]

34. Zdarta, J.; Meyer, A.S.; Jesionowski, T.; Pinelo, M. Developments in support materials for immobilization of oxidoreductases: A comprehensive review. Adv. Colloid Interface 2018, 258, 1-20. [CrossRef] [PubMed]

35. Yu, D.; Ma, Y.; Xue, S.J.; Jiang, L.; Shi, J. Characterization of immobilized phospholipase $\mathrm{A}_{1}$ on magnetic nanoparticles for oil degumming application. LWT Food Sci. Technol. 2013, 50, 519-525. [CrossRef]

36. Qu, Y.; Sun, L.; Li, X.; Zhou, S.; Zhang, Q.; Sun, L.; Yu, D.; Jiang, L.; Tian, B. Enzymatic degumming of soybean oil with magnetic immobilized phospholipase A 2 . LWT Food Sci. Technol. 2016, 73, 290-295. [CrossRef]

37. Mao, X.Z.; Liu, Q.Q.; Qiu, Y.Q.; Fan, X.Q.; Han, Q.Q.; Liu, Y.J.; Zhang, L.J.; Xue, C.H. Identification of a novel phospholipase $\mathrm{D}$ with high transphosphatidylation activity and its application in synthesis of phosphatidylserine and DHA-phosphatidylserine. J. Biotechnol. 2017, 249, 51-58. [CrossRef] [PubMed]

38. Li, B.L.; Wang, J.; Zhang, X.L.; Zhao, B.X. An enzyme net coating the surface of nanoparticles: A simple and efficient method for the immobilization of phospholipase D. Ind. Eng. Chem. Res. 2016, 55, 10555-10565. [CrossRef]

39. Imamura, S.; Horiuti, Y. Enzymatic determination of phospholipase D activity with choline oxidase. J. Biochem. 1978, 83, 677-680. [CrossRef] [PubMed]

(C) 2019 by the authors. Licensee MDPI, Basel, Switzerland. This article is an open access article distributed under the terms and conditions of the Creative Commons Attribution (CC BY) license (http://creativecommons.org/licenses/by/4.0/). 